\title{
MPU法に基づいたボリュームデータの補間と圧縮
}

井上 成治 ${ }^{\circ}$ (立命館大学大学院), 小嶋 一行(立命館大学大学院)

仲田＼cjkstart晋(立命館大学)，田中 覚(立命館大学)

\section{Interpolating and compressing volume data with MPU}

\author{
Seiji INOUE, Kazuyuki KOJIMA, Susumu NAKATA and Satoshi TANAKA
}

\begin{abstract}
Volume visualization is widely used in medical, scientific, and other fields. Since volume data are generally large, data compression techniques become important. In addition, volume data are usually discrete, and must be interpolated to execute volume-visualization algorithms. For high-quality visualization, higher-order smooth interpolation is required. But it is difficult to make such interpolation compatible with the data compression. Recently, the MPU (multi-level partition of unity) method has been developed to reconstruct a smooth implicit surface from a large number of 3D points. Our purpose is to construct a new version of the MPU method that is applicable to interpolate discrete volume data, generating a highly-smooth scalar field described with small-size data. It is demonstrated that the data size is reduced drastically, keeping the smooth feature of the interpolated scalar field.
\end{abstract}

Keywords: Volume visualization, Data compression, MPU, Smoothness

\section{1. 序 論}

現在，医療分野や科学技術分野において，ボリュームビ ジュアライゼーションが重要になっている。これに用い られるデー夕は，3 次元対象の表面形状の情報だけでな く，内部情報も記録されたボリュームデータである.

対象の内部情報も記録されるため, ボリュームデータ は大規模となり，ボリュームビジュアライゼーションの メモリコストは非常に高い. そのため, ボリュームデー 夕に対するデー夕压縮技術が求められている，一方，高 品質な可視化のためには，微分まで含めて連続な補間ス カラー場の生成が必要であるが，そのような補間とデー 夕圧縮の両立は容易でない。また, 既存のボリュームデ 一夕压縮技術 ${ }^{11}$ の多くは, 正規格子構造のデ一夕を対象 としており，不規則・非格子構造のデー夕に対する圧縮 技術はまだ不十分である.

形状計測装置より得られる点群から 3 次元形状を再構 成する方法として陰関数曲面を用いる手法がある.この 手法は入力点群座標の規則性を問わず，表面形状は連続 関数におけるゼ口等值面として表される. 近年, 大規模 点群を対象とし, 形状変化に応じて空間分割, 2 次関数 で補間を行う Multi-level Partition of Unity（MPU） 法2)が提案された.
本研究では，大規模点群から陰関数曲面を生成する MPU 法を応用し, 離散的ボクセル值の集合として与元 られるボリュームデータから， $\mathrm{C}^{\infty}$ 連続なスカラー場を再 構成すると同時に, データ压縮する手法を提案する.

\section{2. ボリュームデータに対応した MPU 法}

まず，簡単に従来のMPU 法を説明する. 従来の MPU 法は離散点群から陰関数曲面を生成する手法である. 離 散点群に対し MPU 法を適用した場合, 離散点群は 2 次 関数で十分補間できるほど単純な形状になるまで 8 分木 に基づいて空間分割され，局所空間で補間される．ある 座標における陰関数值は，その座標を含むすべての局所 空間での関数値を重みつきで足し合わせることで得られ る. 本節では, 上記の MPU 法をボリュームデータに対 応するように改良を加えたVolume MPU法を提案する. 2.1 ボリュームデータを補間する関数

本研究では局所空間を補間する関数として, 0 次関数, 1 関数, 2 関数, Radial Basis Function(RBF) を用いた. 次数が高いほど, より複雑なスカラー場を補間すること ができる.しかしながら，保存しなければならない㛊数 が增えるため, デ一夕圧縮効果は低くなる. RBF は高精 度で補間可能であるが，データ圧縮効果は最も低い． 


\section{2 空間分割と補間}

空間の分割は 8 分木に基づいて行う. 分割され生成さ れた局所空間をセルとよび，また，セルの外接球をサポ 一トと呼ぶことにする，以下に空間分割および補間の手 順を示す.

1）サポート内部に含まれるボクセルを探索する.

2) 1)で得られたボクセル值を 0〜2 次の関数で順次に 補間を試み，入力デ一タとの誤差を調べていく.

3a）2)で計算した䛊差が閵值より小さければ, その補間 関数を採用し, 局所関数 $Q(p)$ とする. その後, 係 数を保存し分割を終了する。

3b）2)で計算した誤差が閥值より大きければ,セルを再 分割する.このとき 8 分割する中心座標は, セル の中心とする.

*）一定回数以上分割しても関数による補間が適切に 行われない場合，1)で得られたボクセル值を RBF で補間し，局所関数 $Q(p)$ とする.

全空間で補間関数が定義されるまで, 上記の処理を再州 的に行う.

\section{3 スカラー值の評価}

補間，生成されたスカラー場上で，ある点 $p$ における スカラ一値 $f(p)$ は

$$
f(\boldsymbol{p})=\sum_{k=1}^{n} \varphi^{(k)}(\boldsymbol{p}) Q^{(k)}(\boldsymbol{p})
$$

として求められる．ただし， $n$ はセルの総数， $\varphi^{(k)}(p)$ は

$$
\sum_{k=1}^{n} \varphi^{(k)}(p)=1
$$

を満たす B-Spline 関数である.

\section{3. 数值実験}

Volume MPU 法の有効性を示すために, 圧縮率の調査を 行った. 以下にその結果を述べる。

対象としたのは Tornadoと呼ばれる正規格子構造の ボリュームデータである. Table 1 に対象データのグリ ッドサイズとデータ量, 及び Volume MPU 法を適用し た後のデー夕量を示す. 入カデータは float 型で記述さ れており，局所関数の係数も float 型で保存している. したがって, データ量は以下のようにして算出した.

$$
\begin{array}{ll}
\text { 入力データ量 }=4 \times(\text { グリッドサイズ }) & \text { (byte) } \\
\text { 出力データ量 }=4 \times(\text { 局所関数の係数の総数 }) & \text { (byte) }
\end{array}
$$

$$
\text { 圧縮率 }=100 \times \frac{(\text { 出力データ })}{\text { (入カデータ })}
$$

Tornado の入出力データで表されるスカラ一場の等値面 を可視化した図を，それぞれ Fig.1に示す.

Fig.1より，スカラ一場は高精度で再現できていること が分かる. また, Table 1より, 入力デー夕に比べ出力 データ量は大きく減少し, 高圧縮率が実現されている.

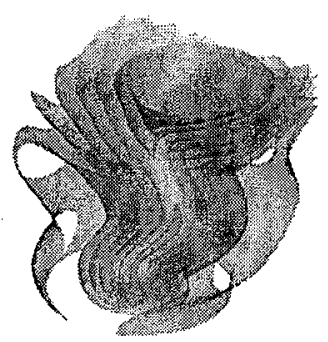

(a)

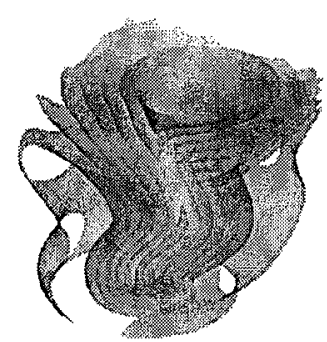

(b)
Fig. 1 Visualized Tornado volume data with isosurfaces : (a) input data, (b) output data.

Table 1 Input and output data size, and the data compressibility.

\begin{tabular}{|c|c|c|}
\hline \multirow{2}{*}{ Input } & Grid size & Tornado \\
\cline { 2 - 3 } & Data size [KB] & 65,536 \\
\hline \multicolumn{2}{|c|}{ Output data size [KB] } & 9,749 \\
\hline \multicolumn{2}{|c|}{ Data compressibility [\%] } & 14.9 \\
\hline
\end{tabular}

以上から, Volume MPU 法はポリュームデータの補間 および圧縮に有効な方法であるといえる.

\section{4. 結論}

本研究では, 陰関数曲面の生成手法である MPU 法を ボリュームデー夕に応用し, ボリュームデー夕を補間お よび圧縮するVolume MPU法を提案した。また，数値 実験として，その適用結果を示した.

奏験結果から，正規格子構造のボリュームデータに Volume MPU 法を適用することにより, 滑らかなスカラ 一場として補間することができ，同時に大幅にデータ量 を削減可能であることが示された.

前述の実験以外に，不規則・非正規格子構造のボリュ 一ムデータに Volume MPU 法を適用する実験を行った ところ，正規格子構造のボリュームデー夕に適用した場 合と同様の結果が得られた.(この結果の詳細は講演時に 述べる.)

現状の Volume MPU 法には, 非常に複雑なスカラー 場を表現するボリュームデータでは圧縮率が低下すると いう問題がある．今後はこのようなデータも圧縮できる よう，スカラー場の変化及び勾配に応じた空間分割と新 たな補間関数の検討を行っていく予定である.

\section{参考文 献}

1) H. T. Tanaka, Y. Takama and H. Wakabayashi : AccuracyBased Sampling and Reconstruction with Adaptive Grid for Parallel Hierarchical Tetrahedrization, In proceedings of IEEE Volume Graphics, 2003, pp.79-86.

2) Y. Ohtake, A. Belyaev, M. Alexa, G. Turk and H. -P. Seidel : Multi-level Partition of Unity Implicits, ACM Transactions on Graphics, Vol.22, No. 3 (2003), pp. 463470. 